\title{
Screening Antimicrobial Potential of Copper Nanoparticles against Pseudomonas fluorescens and Bacillus subtilis and its Sustainability in Agriculture
}

\author{
Shalini Yerukala* and Vidya Sagar Bokka
}

\begin{abstract}
Department of Plant Pathology, College of Agriculture, Rajendranagar, Hyderabad-500030, Telangana, India
\end{abstract}

*Corresponding author

\begin{tabular}{|c|c|}
\hline & B S T R A C T \\
\hline Keywords & \multirow{3}{*}{$\begin{array}{l}\text { Recent times copper nanoparticles }(\mathrm{CuN}) \text { has gained attention due to its multifaceted } \\
\text { action against several microbes. However, its impact on beneficial plant microbes has not } \\
\text { much studied. To fill these knowledge gaps, copper nanoparticles were tested for } \\
\text { antibacterial ability against well-known two plant biocontrol agents Pseudomonas } \\
\text { fluorescens and Bacillus subtilis by an in vitro bioassay using disk diffusion methodology. } \\
\text { Antibacterial activity of CuN was compared with botanicals like clove, pepper and } \\
\text { standard antibiotics like ampicillin and streptomycin. Our study results revealed that CuN } \\
\text { recorded higher eff ectiveness for both } P \text {. fluorescens and B. subtilis with maximum } \\
\text { inhibition zone compared to others tested. Test results illustrate that, bio agents } P \text {. } \\
\text { fluorescens and B. subtilis found to be sensitive to CuN. In conclusion, our research could } \\
\text { help in determination of microbial strain specificity and to better understand nanoparticles } \\
\text { usage for specific purposes. However, further research is needed to better understand CuN } \\
\text { role, mechanisms and impact on beneficial plant microorganism in agriculture. }\end{array}$} \\
\hline Article Info & \\
\hline $\begin{array}{l}\text { Accepted: } \\
\text { 17 May } 2018 \\
\text { Available Online: } \\
\text { 10 June } 2018\end{array}$ & \\
\hline
\end{tabular}

\section{Introduction}

Current advances and emergence of nanoscience or nanotechnology in last few decades showed rapid expansion, providing new opportunities in various fields include medical (Misra et al., 2010; Mitra et al., 2003; Liang et al., 2008; Wang et al., 2008), food industry (Caiyun et al., 2005; Siegrist et al., 2005), molecular diagnostics (Jain, 2003), paints, plastics and textiles, cosmetics, optical, electronic, mechanical and chemical fields etc. (Azam et al., 2012; Mu and Sprando2010; Silva 2006; Goldhaber-Gordon et al., 1997;
Mnyusiwalla et al., 2007). Furthermore, nanotechnology has gained a great deal of attention from the researchers in current times because of its multitasking in various fields.

In recent years increased chemical usage in management of insect pests and plant pathogens has impacted several environmental issues include environmental pollution (Dhaliwal et al., 2010), pest resistance, pest resurgence and residual phytotoxicity problems etc. (Dhaliwal et al., 2010). To reduce the environmental pollution impact caused by chemical pesticides or fungicide 
usage, there is an urgent need to develop an alternate strategy to reduce the concern. One such alternative could be use of metal nanoparticles. Metal nanoparticles has shown potent antibacterial capability against several microbes (Wang et al., 2017).

Metal nanoparticles (MNPs) with antibacterial properties have unique qualities than bulk materials include greater ratio of surface area to volume with larger low-coordinate atoms that are easily available for microbial membranes interactions and further in release of metal ions (Choi et al., 2008). Additionally, the bactericidal property of MNPs could be applied for surface coating, that can have wide application in various fields (Ruparelia et al., 2008).

Furthermore, nanoparticles due its smaller particle size proved to act as good antimicrobial activity (Jones et al., 2008). Moreover, the MNPs antibacterial activities depend mainly on two factors nanoparticlephysico chemical properties and bacteria type (Hajipour et al., 2012). Because of special characters MNPs possess, MNPs could be a potential and sustainable alternative in plant pathogen or plant disease management in agriculture sector. However, thorough research is needed on MNPs usage or application in agriculture field.

Some of the MNPs shown potential antibacterial properties include $\mathrm{ZnO}$ (Sinha et al., 2011), Ag (Morones et al., 2005; Ruparelia et al., 2008; Sinha et al., 2011), $\mathrm{CuO}$ (Ruparelia, et al., 2008, Azam et al., 2012), $\mathrm{Al}_{2} \mathrm{O}_{3}$ (Jiang et al., 2009), $\mathrm{TiO}_{2}$ (Jiang et al., 2009; Tsuang et al., 2008); NiO (Wang et al., 2010), $\mathrm{Fe}_{2} \mathrm{O}_{3}$ etc. (Azam et al., 2012). Despite MNPs are well known for its antimicrobial ability, while in agriculture usage or application must be cautious on MNPs impact or side effect on beneficial microorganisms.
Antimicrobial activity of nanoparticles has mostly documented on human pathogenic bacteria such as Escherichia coli (Ruparelia et al., 2008; Yoon et al., 2007) and Streptococcus aureus etc. (Baek and An, 2011). Further antibacterial activity of nanoparticles mostly depends on MNPs size, MNPs stability and MNPs concentration used in the growth medium. Further, bacterial growth was inhibited due to MNPs interactions with bacteria in growing medium (Raghupati et al., 2011). In comparison between bacterial cells and MNPs sizes, bacterial cells (size) are in micrometers while bacterial outer cell membranes pore (size) range are in nanometers. Whereas, nanoparticles sizeare much smaller than bacterial pore size. Because of MNPs unique ability of smaller size nature, helps MNPs in cell membrane crossing and interactions (Parisi et al., 2015).

Current challenges impacted by climate change, food security motivated researchers in engage and exploration of new areas of science, one such discovery is investigation on nanotechnology as new tool in crop improvements for the agricultural sector. However, despite of numerous reports on nanotechnology advantages in recent times, still there is a lot of uncertainty in research and understanding (Parisi et al., 2015).

Among MNPs, copper nanoparticle is one such metal that has potential antimicrobial activity against several microbial species (Azam et al., 2012). Among various MNPs, copper oxide $(\mathrm{CuO})$ has unique properties such as photoconductive and photothermal applications (Rakhshani et al., 1986), electric, catalytic, optical, nanofluid and photonic. Furthermore, CuN compared to other metal nanoparticles are cheaper, release $\mathrm{Cu}$ ions readily, has greater penetrating ability, cause cell wall disruption and nucleic acid damage (Yoon et al., 2007; Raffi et al., 2010; Rispoli 
et al., 2010), however the exact mechanism of $\mathrm{CuN}$ antimicrobial potentiality is still not clear.

Moreover, $\mathrm{CuO}$ nanoparticles, can be prepared from several plant extracts include Aloe vera (Kumar et al., 2015), Tabernaemontana divaricate (Sivaraj et al., 2014), tea leaf and coffee powder extracts (Sutradhar, et al., 2014), gum karay (Padil and Cernik, 2013) and brown algae, Bifurcaria bifurcate (Abboud et al., 2014). Furthermore, $\mathrm{Cu}$ and $\mathrm{CuO}$ nanoparticles showed potential antimicrobial against several human pathogenic organisms include Bacillus subtilis, E. coli, Vibria cholera, Syphillis typhus, Pseudomonas aeruginosa and Staphylococcus aureus (Akhavan and Ghaderi, 2012; Hassan et al., 2012; Stoimenov et al., 2002), Vibrio cholerae non.0139 and Shigella dysenteriae 1 (Sutradhar, et al., 2014).

We considered $\mathrm{Cu}$ nanoparticles for our study because of its unique characteristics and multi potent action against several microbes. Further investigated to better understand the $\mathrm{CuN}$ effect on beneficial microbes when applied in agriculture, we framed the experiment to determine $\mathrm{Cu}$ nanoparticles effect on two beneficial bioagents include Bacillus subtilis (gram-positive) and Pseudomonas fluorescens (gram-negative) bacterial strains. The objective of this study was to compare the bactericidal effect of copper nanoparticles with botanicals and other commercial antibiotics on beneficial microbial strains and to study the sensitivity of bioagents towards $\mathrm{CuN}$.

\section{Materials and Methods}

All the experiments were carried out at Department of Plant Pathology, College of Agriculture, Rajendranagar, Hyderabad, India. Two bioagents, Pseudomonas fluorescens and
Bacillus subtilis were procured from Directorate of Oil Seeds Research, Rajendranagar, Hyderabad. Nano copper from Osmania University, Hyderabad, India (fig. 2). Botanicals and antibiotics from local market, Hyderabad, India. Efficacy of copper nano, botanicals and antibiotics were evaluated against bacterial bioagents under in vitro condition by disk diffusion assay (Ruparelia et al., 2008). Method followed summarized in the flow chart in the fig. 1 .

\section{Isolation of bacterial bioagents}

The procured bioagent bacterial cultures $P$. fluorescens and B. subtilis were cultured on nutrient agar medium (NA). The inoculated plates were incubated at $28 \pm 2{ }^{\circ} \mathrm{C}$ for one week and were isolated and identified and were used for the further studies.

\section{Disk diffusion assay}

Disk diffusion method was used to evaluate in vitro antibacterial potentiality of copper nanoparticles against two bacterial strains.

\section{Antibacterial activity}

The bacterial suspension $\left(10^{4}-10^{5} \mathrm{CFUml}^{-1}\right)$ was applied on nutrient agar medium surface uniformly.

To determine the antibacterial effect standard paper disk of uniform size $(6 \mathrm{~mm}$ diameter) were impregnated in $5 \mathrm{mgml}^{-1}$ of copper nanoparticles, botanicals like clove, pepper and antibiotics like ampicillin and streptomycin, each disk containing $100 \mu \mathrm{g}$.

Sterile water impregnated disks as a control. The nanoparticle amended filter paper was dried for approximately $1 \mathrm{hr}$. These disks were then placed on to the inoculated nutrient agar medium (4 disks per plate) containing bacteria. 


\section{P. fluorescens}

Tested with copper nanoparticles, botanicals such as clove and pepper impregnated on sterile Whatman No. 1 filter paper disks was used. Not compared with standard antibiotics.

\section{B. subtilis}

Copper nanoparticles, botanicals such as clove, pepper and antibiotics like ampicillin and streptomycin impregnated on sterile Whatman No. 1 filter paper disks were used.

All the inoculated treatment plates were incubated at $35^{\circ} \mathrm{C}$ for $24 \mathrm{hrs}$. Each treatment was replicated thrice. Average inhibition zone diameter $(\mathrm{mm})$ surrounding the discs was measured.

\section{Statistical Analysis}

The experiment was Completely Randomized (CRD). The data obtained was transformed and was statistically analyzed by SAS-9.4 (SAS Institute, Cary, NC). Significant differences were further analyzed by the mean separation test by Least square means (LSD) (Table1.)

\section{Results and Discussion}

The antibacterial activity of copper nanoparticles was investigated on two bioagents include Pseudomonas fluorescens (gram negative bacterium) and Bacillus subtilis (gram-positive bacterium) using the inhibition zonediameter $(\mathrm{mm})$ in disk diffusion test. Generally, the diameter of inhibition zone (DIZ) reveal susceptibility of microorganism to the treatment. Microbes exhibiting larger DIZ reflect susceptibility to the disinfectant or treatment, whereas with smaller DIZ are considered as resistant strains. In our results we noted that disks with copper nanoparticles were surrounded by a larger DIZ (18mm) compared to botanicals such as clove and pepper against in both $P$. fluorescens and $B$. subtilis tested (fig. 2 and 3). Additionally, when tested with antibiotics like ampicillin and streptomycin against B. subtilis, copper nanoparticles were surrounded by a larger DIZ compared with others (fig. 4 and 5). The copper nanoparticles impregnated disks showed high effectiveness compared to other impregnated disks on both the strains of bacteria.

When tested on $P$. fluorescens, copper nanoparticles recorded larger DIZ followed byclove and least was by pepper (fig. 3). In $B$. subtilis, copper nanoparticles $(\mathrm{CuN})$ recorded larger DIZ followed by antibiotics ampilicin and streptomycin, botanical clove and least was by pepper (fig. 4 and 5). Results are summarized in the fig. 6 .

The test copper nanoparticles were found effective on both $P$. fluorescens and B. Subtilis compared to others tested. Thus, our results put forth that $\mathrm{CuN}$ have potential inhibitory property towards target bacteria. We also noted that beneficial microbes i.e. the two bioagents tested were sensitive to $\mathrm{CuN}$. Although our results show that $\mathrm{CuN}$ has antimicrobial potentiality, it clearly illustrates from our results that in agriculture application or usage, special caution needed, as $\mathrm{CuN}$ could be deleterious to beneficial microbes present in soil or beneficial microbes present in plant ecosphere etc. In summary according to our investigation output clarifies that beneficial bioagents tested are sensitive to $\mathrm{CuN}$. Our results of antibacterial property of $\mathrm{CuN}$ are in accordance with the results of Ruparelia et al., 2008; Bogdanovic et al., 2014; Cioffi et al., 2005; Yoon et al., 2007. Similarly, $\mathrm{CuN}$ showed antibacterial activity (DeAlba-Montero et al., 2017) against several microbes include Staphylococcus aureus, Escherichia coli and Candida albicans (Bogdanovic et al., 2014). 
Fig.1 Diagrammatic representation of disk diffusion assay followed in the study

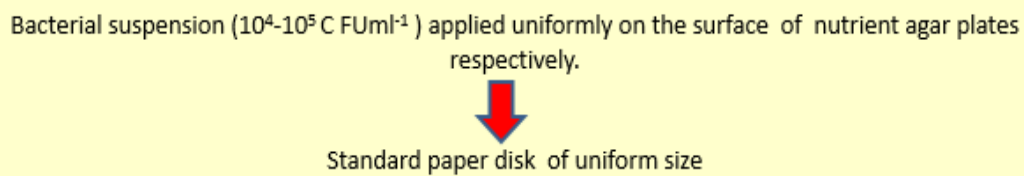

( $6 \mathrm{~mm}$ diameter ) were impregnated in $5 \mathrm{mgml}^{-1}$ of the materials, each disk containing $100 \mu \mathrm{g}$. Sterile water impregnated disks as control.

Disks were then placed on to the inoculated nutrient agar medium ( 4 per plate).

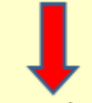

Inoculated plates - incubated at $35^{\circ} \mathrm{C}$ for $24 \mathrm{~h}$.

Average diameter of inhibition zone surrounding discs was measured

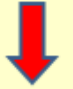

Results were taken based on 3 replication.

Fig.2 Copper nanoparticle powder

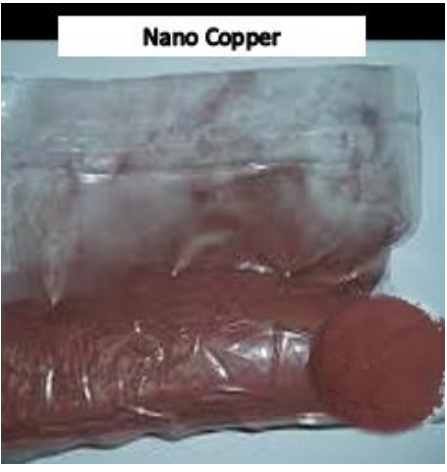

Fig.3 Comparison of copper nanoparticles versus botanicals efficacy on bioagent Pseudomonas fluorescence

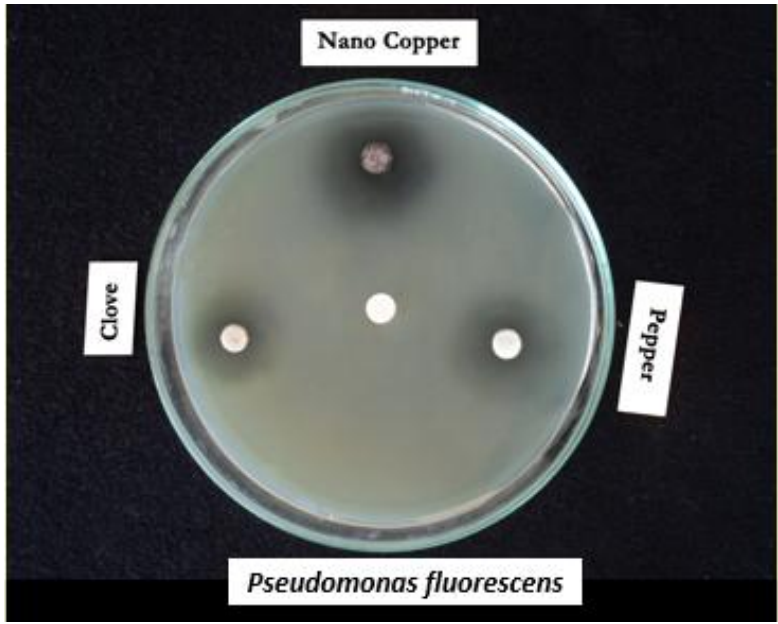


Fig.4 Comparison of copper nanoparticles versus standard antibiotics efficacy onbioagent Bacillus subtilis

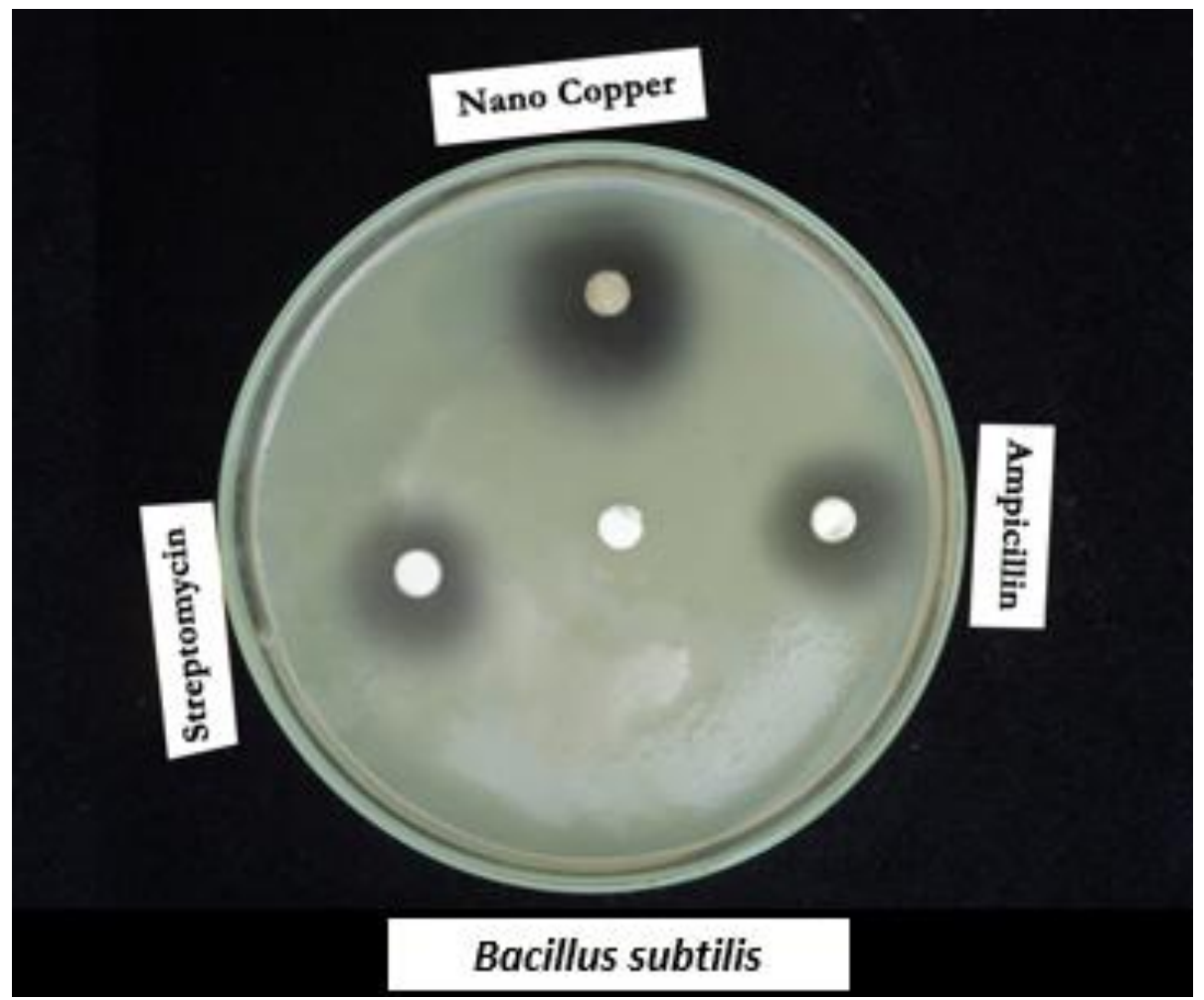

Fig.5 Comparison of copper nanoparticles versus botanicals efficacy on bioagent Bacillus subtilis

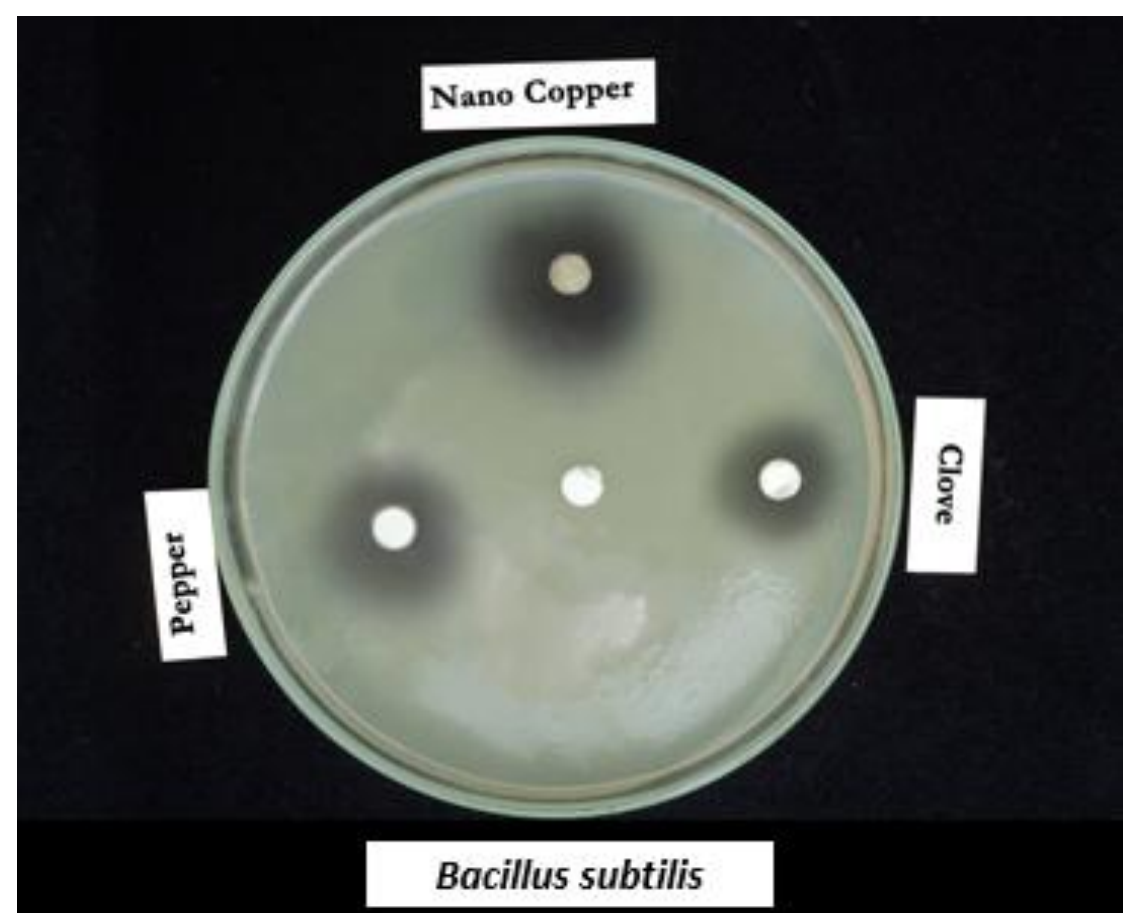


Fig.6 Graphical representation of comparison between copper nanoparticles versus botanicals versus standard antibiotics effect on bioagents Bacillus subtilis and Pseudomonas fluorescence

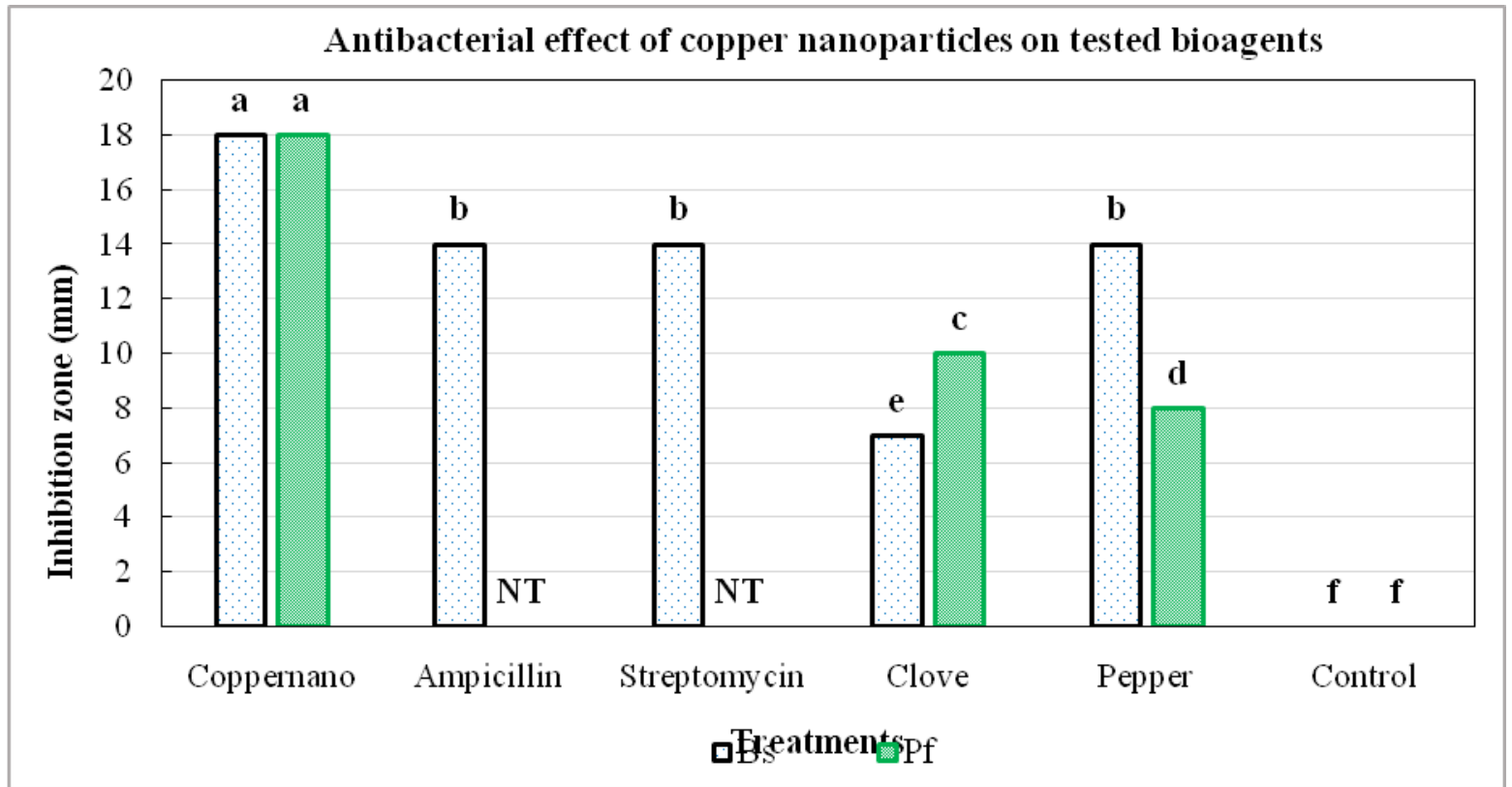

*Mean of three replications, means followed by the same letter in a column are non-significant, at 0.05 level of significance according to LSD. Highest mean is assigned the letter A. NT= not tested, Bs Bacillus subtilis and Pf Pseudomonas fluorescence.

Likewise, Azam et al., 2012 recorded that $\mathrm{ZnO}$ and $\mathrm{CuO}$ nanoparticles showed greatest antibacterial ability against gram-negative bacteria and gram-positive compared to $\mathrm{Fe}_{2} \mathrm{O}_{3}$ nanoparticles.

Antibacterial property of $\mathrm{CuN}$ against Pseudomonas spp. was documented by Longano et al., 2012. Similarly, Kumar et al., 2015 recorded that $\mathrm{CuN}$ exhibited enhanced antibacterial activity against $P$. fluorescens even at lower concentrations i.e. above $20 \mu \mathrm{g} / \mathrm{ml}$ (Kumar et al., 2015). In our studies we found that $P$. fluorescens was sensitive to $\mathrm{CuN}$. Possibly the reason for P. fluorescens sensitivity towards $\mathrm{CuN}$ could be attributed by the fact $P$. fluorescens is a gram-negative bacterium consists of special cell membrane structure (Shahmiri et al., 2013).

Sensitive of B. subtilis to copper nanoparticles in our results are in agreement with Yoon et al., 2007, who reported that copper nanoparticles showed greater antibacterial than silver nanoparticles on $B$. subtilis and $E$. coli. Probable reason for $B$. subtilis susceptibility to $\mathrm{CuN}$ could be attributed to the fact that gram-positive bacterial cell wall consists of thick peptidoglycan layer (Scott and Barnett, 2006) and bacterial cell surface with higher amounts of amines and carboxyl groups (Shahmiri et al., 2013). However, size of $\mathrm{CuN}$ are much smaller that cell pore size. Additionally, Azam et al., 2012 recorded in their findings that gram-positive bacteria showed higher sensitivity than gram-negative towards nanoparticles.

The antibacterial property of $\mathrm{CuN}$ could be attributed by several factors, firstly due to ready release of copper ions in the medium (Cioffi et al., 2005) or by direct nanoparticles interaction on bacterial cell membrane (Ruparelia et al., 2008). Another possibility could be released ions could have attached to cell wall of that bacteria finally leading to cell 
membrane disruption (Chatterjee et al., 2014) or thereby leading to protein denaturation, disruption of biochemical pathway (Kim et al., 2000; Stohs and Bagchi, 1995; Azam et al., 2012). Further released copper ions inside the bacterial cells, get bonded and cross linked to nucleic acid molecule strands internally, resulting in helical structure disorganization (Azam et al., 2012), nucleic acid degradation (Chatterjee et al., 2014), bacterial cell filamentation, reactive oxygen species generation, protein oxidation, lipid peroxidation (Chatterjee et al., 2014) cell killing and ultimately cell death (Yu-sen et al., 2000). The nanoparticles (NPs) can change or manipulate bacteria microenvironment and generate reactive oxygen species and increase NPs solubility, that finally cause bacteria death (Heinlaan et al., 2008)

The toxicity MNPs ions also depends on the properties of heavy metals. Further MNPs toxicity are in relation to the microbial colony size, colony number and the concentration of nanoparticles (NPs) used (Baek and An, 2011). Furthermore, other factors such as nanoparticle diffusion ability may also influence on its effect on target bacteria or microorganism. Nevertheless, further research is needed to confirm the process. However, the mechanism involved for $\mathrm{CuN}$ antimicrobial ability has not been fully understood.

Botanicals tested clove, pepper showed an inhibition effect on the both bacteria tested, however we noted differential inhibition rates. Pepper was highly effective on B. subtilis compared to $P$. fluorescens. While clove was highly effective on $P$. fluorescens compared to $B$. subtilis. However, clove and pepper both have bactericidal properties that have already been documented by many researchers (Nascimento et al., 2000; Karsha and Lakshmi, 2010).
Antibiotics, ampicillin and streptomycin showed effective against $B$. subtilis, and both were on par with each other with inhibition rate and were inferior than $\mathrm{CuN}$ in inhibition rate. The antibacterial property of standard antibiotics ampicillin and streptomycin already has been well established by many research scholars (Schatz et al., 1944; Dyas and Wise, 1983).

In conclusion, in our studies we found that copper nanoparticles have a greater antimicrobial affinity against both bacteria $P$. fluorescens and B. subtilis, in comparison with botanicals like clove, pepper and commercial antibiotics ampicillin and streptomycin. Susceptibility of the bioagents tested P. fluorescens and B. subtilis to copper nanoparticles was recorded. Our study could help to determine microbial strain specificities and provide knowledge on better application of metal nanoparticles for specific purposes. However, further research needed to better understand the relationship between the nanoparticle size and microbe susceptibility index. Before commercialization of $\mathrm{CuN}$, detailed research and comparative study needed to understand $\mathrm{CuN}$ impact on beneficial microorganisms when applied in agriculture.

\section{Future work}

Detailed research should be conducted on metal nanoparticles implications on different beneficial bioagents before utilization in agricultural application. Further metal nanoparticles effect on different bacterial and fungal plant pathogens must be investigated by following effective, inexpensive and ecofriendly technology usage.

\section{Acknowledgements}

The authors are grateful to the College of Agriculture, Rajendhranagar, Hyderabad, 
India for providing the financial assistance and support for conducting this research.

\section{References}

Abboud, Y., Saffaj, T., Chagraoui, A., El Bouari, A., Brouzi, K., Tanane, O., and Ihssane, B. 2014. Biosynthesis, characterization and antimicrobial activity of copper oxide nanoparticles (CONPs) produced using brown alga extract (Bifurcariabifurcata). Applied Nanoscience, 4(5), 571576.https://goo.gl/MKJN4h

Akhavan, O., and Ghaderi, E. 2010. $\mathrm{Cu}$ and $\mathrm{CuO}$ nanoparticles immobilized by silica thin films as antibacterial materials and photocatalysts. Surface and Coatings Technology, 205(1), 219-223. https://doi.org/10.1016/j.surfcoat.2010.06 .036

Azam, A., Ahmed, A. S., Oves, M., Khan, M. S., Habib, S. S., and Memic, A. 2012. Antimicrobial activity of metal oxide nanoparticles against Gram-positive and Gram-negative bacteria: a comparative study. International journal of nanomedicine, 7 , 6003.https://doi.org/10.2147/IJN.S35347

Baek, Y. W., and An, Y. J. 2011. Microbial toxicity of metal oxide nanoparticles $(\mathrm{CuO}, \mathrm{NiO}, \mathrm{ZnO}$, and $\mathrm{Sb} 2 \mathrm{O}$ 3) to Escherichia coli, Bacillus subtilis, and Streptococcus aureus. Science of the Total Environment, 409(8), 1603-1608. https://doi.org/10.1016/j.scitotenv.2011.0 1.014

Bogdanović, U., Lazić, V., Vodnik, V., Budimir, M., Marković, Z., and Dimitrijević, S. 2014. Copper nanoparticles with high antimicrobial activity. Materials Letters, 128, 75-78. https://doi.org/10.1016/j.matlet.2014.04.1 06

Caiyun, L., Wei, Z., Yang, B., Bo-zhong, G., and Wei-qiang, L. 2005. The applications of nanotechnology in food industry $[\mathrm{J}]$.
Science and Technology of Food Industry, 4, 061.https://goo.gl/5iF9J9

Chatterjee, A. K., Chakraborty, R., and Basu, T. 2014. Mechanism of antibacterial activity of copper nanoparticles. Nanotechnology, 25(13), 135101.goo.gl/6t298Q

Choi, O., and $\mathrm{Hu}$, Z. 2008. Size dependent and reactive oxygen species related nanosilver toxicity to nitrifying bacteria. Environmental science \& technology, 42(12), 4583-4588. https://goo.gl/bsxJgD

Cioffi, N., Ditaranto, N., Torsi, L., Picca, R. A., Sabbatini, L., Valentini, A., and Zambonin, P. G. 2005. Analytical characterization of bioactive fluoropolymer ultra-thin coatings modified by copper nanoparticles. Analytical and bioanalytical chemistry, 381(3), 607-616.https://goo.gl/pAV4nT

Cioffi, N., Torsi, L., Ditaranto, N., Tantillo, G., Ghibelli, L., Sabbatini, L., and Traversa, E. 2005. Copper nanoparticle/polymer composites with antifungal and bacteriostatic properties. Chemistry of Materials, 17(21), 5255-5262. https://goo.gl/45rWjg

DeAlba-Montero, I., Guajardo-Pacheco, J., Morales-Sánchez, E., Araujo-Martínez, R., Loredo-Becerra, G. M., MartínezCastañón, G. A., and Compeán Jasso, M. E. 2017. Antimicrobial properties of copper nanoparticles and amino acid chelated copper nanoparticles produced by using a soya extract. Bioinorganic chemistry and applications. Article ID 1064918, 6 pages. https://doi.org/10.1155/2017/1064918

Dhaliwal, G. S., Jindal, V., and Dhawan, A. K. 2010. Insect pest problems and crop losses: changing trends. Indian Journal of Ecology, $\quad 37(1), \quad$ 1-7. https://goo.gl/4Xmahx

Dyas, A., and Wise, R. 1983. Ampicillin and alternatives. British medical journal (Clinical research ed.), 286(6365), 583. https://goo.gl/VsdBBR

Goldhaber-Gordon, D., Montemerlo, M. S., Love, J. C., Opiteck, G. J., and Ellenbogen, J. C. (1997). Overview of 
nanoelectronic devices. Proceedings of the IEEE, 85(4), 521-540. https://goo.gl/gNAvxr

Hajipour, M. J., Fromm, K. M., Ashkarran, A. A., de Aberasturi, D. J., de Larramendi, I. R., Rojo, T., and Mahmoudi, M. 2012. Antibacterial properties of nanoparticles. Trends in biotechnology, 30(10), 499511.https://doi.org/10.1016/j.tibtech.2012 .06 .004

Hassan, M. S., Amna, T., Yang, O. B., ElNewehy, M. H., Al-Deyab, S. S., and Khil, M. S. 2012. Smart copper oxide nanocrystals: synthesis, characterization, electrochemical and potent antibacterial activity. Colloids and Surfaces B: Biointerfaces, 97, 201-206. https://doi.org/10.1016/j.colsurfb.2012.04 .032

Heinlaan, M., Ivask, A., Blinova, I., Dubourguier, H. C., and Kahru, A. 2008. Toxicity of nanosized and bulk $\mathrm{ZnO}, \mathrm{CuO}$ and $\mathrm{TiO} 2$ to bacteria Vibrio fischeri and crustaceans Daphnia magna and Thamnocephalusplatyurus. Chemosphere, 71(7), 1308-1316. https://doi.org/10.1016/j.chemosphere.20 07.11 .047

Jain, K. K. 2003. Nanodiagnostics: application of nanotechnology in molecular diagnostics. Expert review of molecular diagnostics, 3(2), 153-161. https://doi.org/10.1586/14737159.3.2.153

Jiang, W., Mashayekhi, H., and Xing, B. 2009. Bacterial toxicity comparison between nano-and micro-scaled oxide particles. Environmental pollution, 157(5), 16191625.

https://doi.org/10.1016/j.envpol.2008.12. 025

Jones, N., Ray, B., Ranjit, K. T., and Manna, A. C. 2008. Antibacterial activity of $\mathrm{ZnO}$ nanoparticle suspensions on a broad spectrum of microorganisms. FEMS microbiology letters, 279(1), 71-76. https://doi.org/10.1111/j.15746968.2007.01012.x

Karsha, P. V., and Lakshmi, O. B. 2010. Antibacterial activity of black pepper
(Piper nigrum Linn.) with special reference to its mode of action on bacteria. Indian Journal of Natural Products and Resources. 1 (2), pp. 213215. https://goo.gl/D8mmdz

Kim, J. H., Cho, H., Ryu, S. E., and Choi, M. U. 2000. Effects of metal ions on the activity of protein tyrosine phosphatase VHR: highly potent and reversible oxidative inactivation by $\mathrm{Cu} 2+$ ion. Archives of Biochemistry and Biophysics, 382(1), 7280.

https://doi.org/10.1006/abbi.2000.1996

Kumar, P. V., Shameem, U., Kollu, P., Kalyani, R. L., and Pammi, S. V. N. 2015. Green synthesis of copper oxide nanoparticles using Aloe vera leaf extract and its antibacterial activity against fish bacterial pathogens. BioNanoScience, 5(3), 135139.https://goo.gl/eQ5Pzc

Liang, H. Y., Hu, D., and Xiao, H. M. 2008. Application of Nanotechnology for Preservation of Fruit and Vegetable. Storage \& Process, 5, 021. https://goo.gl/bSwSLp

Longano, D., Ditaranto, N., Cioffi, N., Di Niso, F., Sibillano, T., Ancona, A., and Torsi, L. 2012. Analytical characterization of laser-generated copper nanoparticles for antibacterial composite food packaging. Analytical and bioanalytical chemistry, 403(4), 1179-1186. https://doi.org/10.1007/s00216-0115689-5

Misra, R., Acharya, S., and Sahoo, S. K. 2010. Cancer nanotechnology: application of nanotechnology in cancer therapy. Drug Discovery Today, 15(19), 842-850. https://doi.org/10.1016/j.drudis.2010.08.0 06

Mitra, S. B., Wu, D., and Holmes, B. N. 2003. An application of nanotechnology in advanced dental materials. The Journal of the American Dental Association, 134(10), 13821390.https://doi.org/10.14219/jada.archiv e.2003.0054

Mnyusiwalla, A., Daar, A. S., and Singer, P. A. 2003. 'Mind the gap': science and ethics 
in nanotechnology. Nanotechnology, 14(3), R9. https://goo.gl/BGtcn3

Morones, J. R., Elechiguerra, J. L., Camacho, A., Holt, K., Kouri, J. B., Ramírez, J. T., and Yacaman, M. J. 2005. The bactericidal effect of silver nanoparticles. Nanotechnology, $\quad 16(10), \quad 2346$. https://goo.gl/W843gH

Mu, L., and Sprando, R. L. 2010. Application of nanotechnology in cosmetics. Pharmaceutical research, 27(8), 17461749. https://goo.gl/1TGFqA

Nascimento, G. G., Locatelli, J., Freitas, P. C., and Silva, G. L. 2000. Antibacterial activity of plant extracts and phytochemicals on antibiotic-resistant bacteria. Brazilian journal of microbiology, 31(4), 247-256. http://dx.doi.org/10.1590/S151783822000000400003

Padil, V. V. T., and Černík, M. 2013. Green synthesis of copper oxide nanoparticles using gum karaya as a biotemplate and their antibacterial application. International Journal of Nanomedicine, 8 , 889.https://doi.org/10.2147/IJN.S40599

Parisi, C., Vigani, M., and Rodríguez-Cerezo, E. 2015. Agricultural nanotechnologies: what are the current possibilities?.Nano Today, 10(2), 124-127. https://doi.org/10.1016/j.nantod.2014.09. 009

Raffi, M., Mehrwan, S., Bhatti, T. M., Akhter, J. I., Hameed, A., Yawar, W., and ul Hasan, M. M. 2010. Investigations into the antibacterial behavior of copper nanoparticles against Escherichia coli. Annals of Microbiology, 60(1), 75-80. https://goo.gl/kfjgnx

Raghupathi, K. R., Koodali, R. T., and Manna, A. C. 2011. Size-dependent bacterial growth inhibition and mechanism of antibacterial activity of zinc oxide nanoparticles. Langmuir, 27(7), 40204028.

Rakhshani, A. E. 1986. Preparation, characteristics and photovoltaic properties of cuprous oxide-a review. Solid-State Electronics, $\quad 29(1), \quad 7-17$. https://doi.org/10.1016/0038-

1101(86)90191-7.

Rispoli, F., Angelov, A., Badia, D., Kumar, A., Seal, S., and Shah, V. 2010. Understanding the toxicity of aggregated zero valent copper nanoparticles against Escherichia coli. Journal of Hazardous Materials, $\quad$ 180(1), 212-216. https://goo.gl/tK58Wq

Ruparelia, J. P., Chatterjee, A. K., Duttagupta, S. P., and Mukherji, S. 2008. Strain specificity in antimicrobial activity of silver and copper nanoparticles. Acta biomaterialia, 4(3), 707-716. https://doi.org/10.1016/j.actbio.2007.11.0 06

Schatz, A., Bugle, E., and Waksman, S. A. 1944. Streptomycin, a Substance Exhibiting Antibiotic Activity Against Gram-Positive and Gram-Negative Bacteria.*. Proceedings of the Society for Experimental Biology and Medicine, 55(1), 66-69. https://goo.gl/1Z9brF

Scott, J. R., and Barnett, T. C. 2006. Surface proteins of gram-positive bacteria and how they get there. Annu. Rev. Microbiol., $\quad 60, \quad 397-423$. https://goo.gl/fCMXSQ

Shahmiri, M., Ibrahim, N., Shayesteh, F., Asim, N., and Motallebi, N. 2013. Preparation of PVP-coated copper oxide nanosheets as antibacterial and antifungal agents. Journal of Materials Research, 28(22), 3109-3118.doi:10.1557/jmr.2013.316

Siegrist, M., Cousin, M. E., Kastenholz, H., and Wiek, A. 2007. Public acceptance of nanotechnology foods and food packaging: The influence of affect and trust. Appetite, 49(2), 459466.https://doi.org/10.1016/j.appet.2007. 03.002

Silva, G. A. 2006. Neuroscience nanotechnology: progress, opportunities and challenges. Nature Reviews Neuroscience, 7(1), 65-74. https://goo.gl/SHwwz4

Sinha, R., Karan, R., Sinha, A., andKhare, S. K. 2011. Interaction and nanotoxic effect of 
$\mathrm{ZnO}$ and $\mathrm{Ag}$ nanoparticles on mesophilic and halophilic bacterial cells. Bioresource technology, 102(2), 1516-1520. https://doi.org/10.1016/j.biortech.2010.07 .117

Sivaraj, R., Rahman, P. K., Rajiv, P., Salam, H. A., and Venckatesh, R. 2014. Biogenic copper oxide nanoparticles synthesis using Tabernaemontana divaricate leaf extract and its antibacterial activity against urinary tract pathogen. Spectrochimica Acta Part A: Molecular and Biomolecular Spectroscopy, 133, 178-181. https://doi.org/10.1016/j.saa.2014.05.048

Stohs, S. J., and Bagchi, D. 1995. Oxidative mechanisms in the toxicity of metal ions. Free radical biology and medicine, 18(2), 321-336. https://goo.gl/e1nqdi

Stoimenov, Peter K., et al., "Metal oxide nanoparticles as bactericidal agents." Langmuir 18.17 (2002): 6679-6686. DOI:10.1021/la0202374

Sutradhar, P., Saha, M., and Maiti, D. 2014. Microwave synthesis of copper oxide nanoparticles using tea leaf and coffee powder extracts and its antibacterial activity. Journal of Nanostructure in Chemistry, 4(1), 86.https://goo.gl/2FCvAs

Tsuang, Y. H., Sun, J. S., Huang, Y. C., Lu, C. H., Chang, W. H. S., and Wang, C. C. 2008. Studies of photokilling of bacteria using titanium dioxide nanoparticles. Artificial Organs, 32(2), 167174.https://DOI: $\quad 10.1111 / \mathrm{j} .1525$ 1594.2007.00530.x
Wang, L., Hu, C., and Shao, L. 2017. The antimicrobial activity of nanoparticles: present situation and prospects for the future. International journal of nanomedicine, 12 , 1227.https://doi.org/10.2147/IJN.S12195 6

Wang, X., Yang, L., Chen, Z. G., and Shin, D. M. 2008. Application of nanotechnology in cancer therapy and imaging. $C A$ : $a$ cancer journal for clinicians, 58(2), 97110. https://DOI: 10.3322/CA.2007.0003

Wang, Z., Lee, Y. H., Wu, B., Horst, A., Kang, Y., Tang, Y. J., and Chen, D. R. 2010. Anti-microbial activities of aerosolized transition metal oxide nanoparticles. Chemosphere, 80(5), 525-529. https://doi.org/10.1016/j.chemosphere.20 10.04.047

Yoon, K. Y., Byeon, J. H., Park, J. H., and Hwang, J. 2007. Susceptibility constants of Escherichia coli and Bacillus subtilis to silver and copper nanoparticles. Science of the Total Environment, 373(2), 572575.

https://doi.org/10.1016/j.scitotenv.2006.1 1.007

Yu-sen, E. L., Vidic, R. D., Stout, J. E., McCartney, C. A., and Victor, L. Y. 1998. Inactivation of Mycobacterium avium by copper and silver ions. Water Research, 32(7), 19972000.https://doi.org/10.1016/S00431354(97)00460-0

\section{How to cite this article:}

Shalini Yerukala and Vidya Sagar Bokka. 2018. Screening Antimicrobial Potential of Copper Nanoparticles against Pseudomonas fluorescens and Bacillus subtilis and Its Sustainability in Agriculture. Int.J.Curr.Microbiol.App.Sci. 7(06): 1606-1617. doi: https://doi.org/10.20546/ijcmas.2018.706.192 